\title{
Gendering Migration Across Euro-Mediterranean Borders: Syrian Refugee Women on the Way to Europe
}

\author{
Nurcan Özgür Baklacığlu*
}

\begin{abstract}
The following paper explores a "hidden" aspect of the Syrian refugee movement across the Euro-Mediterranean that still has not grasped the attention of the researchers: the Syrian women passages across the Central Mediterranean border. Since half a decade, the Syrian women have been experiencing and coping with various challenges across the land and sea borders on the Euro-Mediterranean route. Founded on gender-based traectory tracking and practice analysis approach, the paper focuses on the ways Syrian women experience the Euro-Mediterranean border crossings and how the regional and especially EU-led border security industry affect their lives in the Middle East and Europe. Based on empirical data retrieved through selected interviews, life-story reports and institutional and practice analyses of the situation of Syrian women in Lebanon, and Jordan the paper answers the following questions: -Why and how the Syrian women leave Lebanon and Jordan? What physical, institutional and political borders and border performances they encounter during their journey from North Africa towards the Europe? How the EU border security operations affect their passages and lives?
\end{abstract}

Keywords: Syrian Women, EU Border Policy, Lebanon, Jordan, Libya, Mediterranean

Assoc. Prof., Istanbul University, Faculty of Political Science and International Relations, nurcanozgur@hotmail.com 


\title{
Avrupa-Akdeniz Bögesindeki Sınır Geçişlerinde Toplumsal Cinsiyet: Avrupa Yolunda Suriyeli Mülteci Kadınlar
}

\author{
Nurcan Özgür Baklacığlu*
}

Öz

Araştırma, Suriye mülteci hareketinin Avrupa-Akdeniz hattında yaşanan ve henüz araştırmacılar arasında çalışılmamış bir boyutunu ele almaktadır: Suriyeli kadınların Avrupa-Akdeniz sınır geçişleri esnasında karşı karşıya kaldıkları pratikler ve sorunlar. Savaşın başlamasından bu yana Suriyeli kadınlar Avrupa-Akdeniz hattında kara ve deniz sınırlarında dolaşmakta ve geçiş yapmakta ve çok farklı uygulama ve sorunlarla karşı karşıya kalmakta ve mücadele etmektedir. Toplumsal cinsiyet perspektifiyle uygulamanın analizine odaklanan bir yaklaşımla ele alınan çalışma, Lübnan, Ürdün ve Libya'da AB ülkeleri yönünde göçe yönelen Suriyeli kadınların sınır deneyimlerini araştırmakta ve AB'nin finanse ettiği sınır güvenlik operasyonlarının kadınların yaşamları üzerindeki etkisini saptamaya çalışmaktadır. Suriyeli kadınlarla sınır geçişleri konusunda yapılan seçili mülakatlara, kadınların kendileri tarafından dile getirilen hikâyeler, raporlar ve makalelerden toplanan verilere dayalı çalışma, Lübnan ve Ürdün'de Suriyeli kadınların karşı karşıya kaldıkları sorunları özetledikten sonra şu sorulara cevap aramaktadır: Neden Suriyeli kadınlar Lübnan ve Ürdün'den göç eder? Ne tür ikincil hareketlerde bulunurlar? Avrupa istikametindeki yolculuklarında ne tür fiziksel, kurumsal ve siyasi sınırları aşmak durumunda kalmakta? AB'nin sınır güvenliği operasyonları kadınların sınır geçişi öncesi ve sonrası yaşamlarını nasıl etkilemektedir?

Anahtar Kelimeler: Suriyeli Kadınlar, AB Sınır Operasyonları, Lübnan, Ürdün, Libya, Akdeniz

Doç. Dr. İstanbul Üniversitesi, Siyasal Bilgiler Fakültesi ve Uluslararası İlişkiler Bölümü, nurcanozgur@hotmail.com 


\section{Introduction}

The ongoing war in Syria followed a wide regionalization of the refugee flows across the Euro-Mediterranean region. Broad migration and geopolitical literature has accumulated around the problems and challenges that rose as a result of the biggest refugee movement of this century. Since 2014, we are observing a growing gender-based perspective focused mainly on the problems that Syrian women encounter under displacement both in Syria, and abroad. Yet, there is a hidden aspect that still has not grasped the attention of the researchers: the Syrian women on the move across borders. There are some studies about the border passages of the African women, but still no studies about the border crossings of the Syrian women have been laboured.

Extending along North Africa and South Europe, the Euro-Mediterranean region is one of the hardest transit regions that refugees use to transpass on their way to Europe. Since the beginning of the century the African women refugees and migrants developed various passage strategies of survival on this route. ${ }^{1}$ The Syrian refugee women have been experiencing and coping with the challenges across the land and sea borders on the Euro-Mediterranean route since the last five years, yet there are no studies investigating their experience along the Euro-Mediterranean passage route. One of the main reasons for this is the fact that because of some cultural prejudices and fears, the Syrian women avoid talking about the border passages and gender-based violence that undergo. From more than 20 women approached in Istanbul and Şanlıurfa, only 6 responded to our request to share the memories of their journeys with us. ${ }^{2}$ There is still no fieldwork about Syrian women border experiences across the Euro-Mediterranean.

Founded on gender-based traectory tracking and practice analysis approach the following paper focuses on the ways Syrian women experience the Euro-Mediterranean border crossings and how the regional and especially EU-led border securitization affect their lives across the Euro-

Sharon Pickering, Women, Borders, and Violence: Current Issues in Asylum and Forced Migration, New York: Springer, 2011; Jane Freedman, "Engendering Security at the Borders of Europe: Women Migrants and the Mediterranean 'Crisis"', Journal of Refugee Studies, Say1 29/4, 1 December 2016.

2 Four of the interviews/conversations were realized by Şule Gürle in Urfa, the other two were taken by Nurcan Özgür Baklacioglu in Istanbul. 
Mediterranean. The study appropriates an intersectional conception of the border as a physical line, wall, boundary, institution, policy, practice, and performance. ${ }^{3}$ Based on empirical data consisted of above mentioned selected interviews with 6 Syrian women in Şanliurfa and Istanbul, IO's data reports on Euro Meditteranean border crossings, and refugee women lifestory reports, the paper answers the following questions: Why the Syrian women initiate secondary migration to the EU? What physical, institutional and political borders and border performances they encounter during their journey towards Europe? How the EU border security and management policies and operations affect their crossings and further experiences?

Blind to the gender aspect of migration and asylum, the available data on migration and border crossings across Euro-Mediterranean routes is being usually collected and categorized according to the age, detection, deaths, passage region, country of origin or country of destination. ${ }^{4}$ It is rarely possible to find a gender-segregated data. Therefore, while analysing contexts, passage practices and performances I will have to use non-gendered data under the assumption that majority of the Syrian movements are gender mixed movements that involve almost 50 percent women refugees. ${ }^{5}$ It is also rather difficult to find data and knowledge about the single Syrian women journeys across the land and sea borders in the Mediterranean. However, since 2016 there is a growing effort on gender-based data accumulation, but the data produced about the deaths and border crossings are usually not comprehensive, but limited in context and scope. Indeed, as we see in the cases of Jordan and Lebanon, it is almost impossible to generate reliable data about clandestine movements across the porous borders.

David Newman, "Boundaries, Borders and Barriers: Changing Geographic Perspectives on Territorial Lines", (Ed.) M. Albert at all, Identities, Borders and Orders, University of Minnesota Press, Minneapolis, 2001; Anssi Paasi, "The Changing Discourses on Political Boundaries: Mapping the Backgrounds, Contexts and Contents", Henk Van Houtum, Olivier Kramsch, Zierhofer Wolfgang (Ed.), B/Ordering Space, Ashgate, London, 2005, p.17-31; Henk Van Houtum, "The Geopolitics of Borders and Boundaries“, Geopolitics, No/ 4/10, November 2005, p. 672-679.

4 See: Frontex, Eurostat, Missing Migrants project, IOM databases. For problems related to the migration data collection and segregation techniques see: Tamara Last and Thomas Spijkerboer, Tracking Deaths in the Mediterranean, Working Paper, SSRN, 2014, p.

5 This data is usually cited by UNHCR, www.unhcr.org; Also see: Sharon Pickering, Rebecca Powell, "Death at the Sea: Migration and the Gendered Dimentions of Border Insecurity", A Gendered Approach to the Syrian Refugee Crisis, Jane Freedman, Zeynep Kivilcim, Nurcan Özgür Baklacıoğlueds., London: Routledge, 2017 


\section{Why Leaving Lebanon And Jordan? Push-Pull Factors Behind The Secondary Movements Of Syrian Women In Jordan And Lebanon}

Lack of opportunities for self-realization, protracted dependency and lack of prospects for building sustainable and safe life are considered as the major push factors behind the secondary migrations initiated among the people under displacement. These push factors use to develop as outcomes of asylum policies and practices in the countries of residence. There are numerous structural push factors behind the motives for secondary movements among the Syrian women in Lebanon and Jordan. Both Lebanon and Jordan host the biggest per capita refugee populations in the region: including Palestinian, Syrian, Iraqis, Libyans, African, Yemenis, and Egypt refugees.(Figure 1) Both Lebanon and Jordan have relatively small but diversified populations containing about 30-40 percent migrants and refugees.

Figure 1: Distirbution of Syrian Refugees in the Middle East ${ }^{6}$

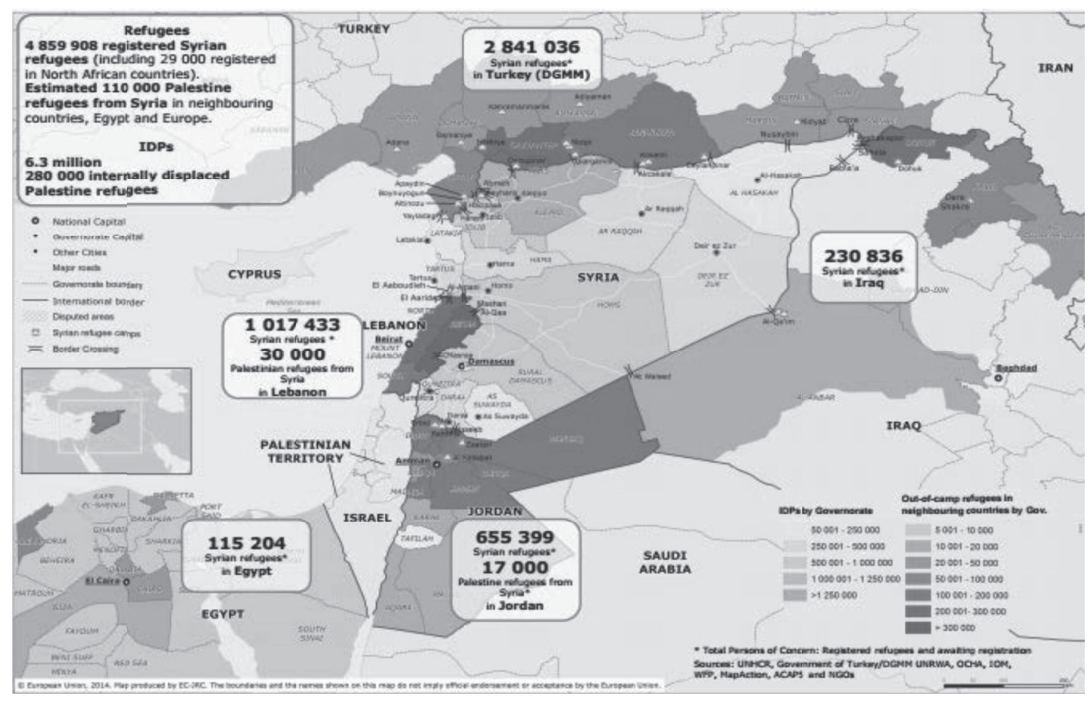

Both countries accepted the Syrian refugees under an ambiguous status of "guests" or "Arab brothers". These terms do not provide any legal status

Data updated on the following map: EU, Refugee Situation and Internal Displacement, Syrian Refugee Map, 27 August 2014, www.pinterest.com 
and access to the rights for the Syrian refugees while bring a rather exclusionary approach in regard to gender and ethnic identity of the Syrian refugees. ${ }^{7}$ Both Lebanon and Jordan are not signatories of the 1951 Convention, thus both do not provide a Convention refugee status to the Syrian refugees. Both states approach Syrians as displaced people under temporary protection. While Lebanon allowed Syrian refugees for out-of-camp residence, Jordan imposed camp-based settlement to the Syrian refugees in city-like Za'atari, Emirates, Cyber-City and Azraq camps. ${ }^{8}$ Jordan has avoided providing legal employment opportunities for the Syrians and the 2015 Ministry of Labor regulation of Lebanon has also banned the obtaining of legal employment for Syrian refugees in the country, too. ${ }^{9}$

Lebanon hosts the highest number of refugees per capita in the Middle East and the whole world. Beside the Palestinian refugees who use to live there since the last century, Lebanon received 1.06 million Syrian refugees and 30,000 Palestine refugees who constitute more than 25 percent of the whole population in Lebanon. Although Jordan accepted 655,000 Syrian refugees, less than Lebanon, the overall high percentage (40\%) of foreign population in the country is being perceived as a security threat to the country. Similarly, due to the sensitive religious structure divided between 30 percent Shiis, 30 percent Christians, and 30 percent Sunnis, Lebanon perceives Syrian refugees as an economic, political and sectarian threat to the already fragile political situation in the country ${ }^{10}$. Sharing a common border with the war in Syria, both Lebanon and Jordan shifted towards selective acceptance of the Syrian refugees and put forth diplomacy for establishing "safe zones" in Syria or out of their borders.

On the other hand, as official data shows, 75 percent of the Syrian refugee population consists of women, children and there is also a fair proportion

7 Ayham Dalal, "Syrian Refugees in Jordan: Potentials, Challenges and the Right to the City", International Community and Refugees: Responsibilities, Possibilities and Human Rights Violations, Turkey: Amnesty International, 2016, p.41-47.

8 Oytun Orhan, The Situation of Syrian Refugees in the Neighbouring Countries: Fingings, Conclussions and Recommendations, ORSAM Report No: 189, Ankara, April 2014

9 Murat Tinas, "Syrian Refugees in Lebanon: Economic, Political, and Sectarian Challenges in the absence of Governmental Strategy", ORSAM Review of Regional Affairs, No.62, May 2017 Ibid. 
of elderly men. This gender and age segregated data rate down the reliability of the security fears. In both cases Syrian refugee children constitute 50-53 percent and women 24-25.9 percent of the refugee population. Majority of the Syrian refugee women are widows or unaccompanied married women whose husbands voluntarily or forcefully disappeared. ${ }^{11}$ This suggests that the number of women heads of the families is relatively high. About 70 percent of the refugee population undergoes hard safety and poverty problems due to a lack of consistent income.(except the food voucher of 15-27 US Dollars per month in Lebanon) ${ }^{12}$ According to UNHCR in Lebanon, at least 10 percent of the women and children are in urgent need of resettlement. The studies show that based on the devastating living conditions many refugee women and girls find themselves within the whirlpool of social and sexual exploitation, slavery and human trafficking. The reports touch upon the open slavery markets in Lebanon and emphasize the growth in the human trafficking market since 2013. The Eurostat data shows that women and children constitute 75 percent of the victims of human trafficking, and 96 percent of the victims of sex trafficking. ${ }^{13}$

The high costs and the restrictions on the renewal of the residence permits leave Syrian women open to sexual violence and abuse at different administrative, camp, district and work place settings. For example, about 86 percent of the Syrian Palestinian refugees are left out of any official residence permit. Because of the lack of residence permit majority of Palestinian and Syrian women refugees are being afraid of being apprehended and deportation, thus they lack any safety and live like prisoners at their homes and districts, between the home and workplace. Due to informal employment, low wages that do not meet the high rents and lack/limit of food aid the structural poverty is unavoidable. Data shows that 93 percent of the Syrian urban refugees in Jordan live under the poverty line. ${ }^{14}$

11 H. Kesgin, A. Öztürk, "The bitter truth behind Syrian War: Desperate Widows", Anadolu Agency News, 10 February 2014

12 Kathryn Ramsay, "The Situation of Refugee Women in Lebanon", International Community and Refugees: Responsibilities, Opportunities, Human Rights Violations, Amnesty International (ed.), Istanbul, 2016, p.33-41

13 European Commission, Study on the Gender Dimension of the Trafficking in Human Beings, Publications Office of the European Union, Lüksemburg, 2016, p. 4.

14 Elena Fiddian-Qasmiyeh, "Palestinian and Syrian Refugees in Lebanon: Sharing Space, Electricity and the Sky", Refugee History, 22 December 2016, www.refugeehistory.org 
Almost all of the children in Jordan remain out of school. In Lebanon the children are registered in the public school system but in fact do not show attendance to the school. Xenophobia, poverty, social exploitation, and fear of sexual harassment and abuse prevent Syrian children from having regular access to education. While the middle-class refugees have relatively sufficient access to education and various health services, the poor refugee children remain without any opportunities for education and professional improvement. Syrian boys use to work in the informal sector while girls are often target to various forced marriage or sexual exploitation attempts hidden behind various personal aid and assistance offers. The lack of official residence creates obstacles in reporting cases of sexual abuse and harassment to the police..$^{15}$ All this follows a growth in the circle of violence that Syrian women use to cope with since the beggining of the war.

Constructed by the asylum policies of the Lebanese and Jordanian governments, all this legal and structural violence obstructs any opportunities for self-reliance and building a sustainable future. As a result, the refugees who have sufficient economic resources or family and friendship networks in the EU member states seem prone to undertake a journey to the EU-28. The relatively high income, education, safety and self-reliance opportunities are among the main pull factors that convince refugees to search for their future at the European borders. While the restrictive immigration policies and laws guide the refugees towards clandestine routes, the misinformation and motivation strategies implemented by the migrant blogs, smugglers and human traffickers constitute a push factor that promotes the journey as a safe, fast and easy process.

Nevertheless, the gender-based motivations behind the decisions to undertake a journey to the EU differ according to both context and the intersection between race, class, rural-urban and educational background. In contrast to male refugees, women refugees use to have rather low and inconsistent income. Because of the patriarchal family structure the employment rate among the Syrian refugee women remain usually low and their decision making performances are usually dependent on their status in the family and family network. Thus the decision to leave is usually not

15 Jane Freedman, Zeynep Kivilcim, Nurcan Özgür Baklacığlu eds., A Gendered Approach to the Syrian Refugee Crisis, London: Routledge, 2017. 
an individual one, except in cases of violence or abuse in the private space. Moreover, the high degree of sexual harassment and abuse against women refugees in the Euro-Mediterranean raise important handicaps that prevent women from undertaking any individual secondary movement. The fear of sexual violence and the lack of material resources to pay to the smugglers are the main handicaps that prevent Syrian women from leaving Lebanon and Jordan.

Nevertheless, lots of Syrian women found themselves crossing the EuroMediterranean borders together with their families or alone. For many years there was no available data about women passages across the Mediterranean and the public used to hear about dead women and children bodies left at the shores. In 2017 the IOM and UNHCR reports published some partial data about the women detected at the Euro-Mediterranean borders. A recent report shows that the number of Syrian women who arrived to Italy increased from 63 in 2012 up to 6,203 in 2014 and dropped to 1,237 in 2015 and 212 in $2016 .{ }^{16}$ But these are partial numbers and do not show the women border-crossings through the Eastern and Western Mediterranean. In general, there is no reliable number about the rate or number of Syrian women among the Syrian refugees crossing the Euro-Mediterranean borders. It is known that the Syrian women are not individually registered, but included in the record of their husbands, brothers or fathers who are usually the heads of the family. There is no data about the border crossings of single women as well, except some recent trafficking data. The available data also shows that compared to the African women the number of the Syrian women remain limited and involves usually the accompanied women. ${ }^{17}$ Also we know that since the launch of the NATO-supported Triton operations the Syrian passages at the Central Mediterranean shifted to the Western or Eastern Mediterranean and Balkan route. During those cyclic and long journeys Syrian women had to pass through numerous militarized militia and state land borders.

16 IOM, Human Traficking through the Central Mediterranean: Data, Stories and Information Collected by the IOM, Italy, October 2017.

17 UNHCR, Refugees/Migrants Emergency Response-Mediterranean, 2016. 


\section{Living Through The Borders: Border Camps, Limbo Zones, Clandestine Crossings}

A travel to refuge starts from the war zone and goes through numerous state, tribe, and militia borders. Most of those borders are controlled by armed men. Thus the main challenge for refugee women is to trespass through these borders safely, avoiding potential sexual harassment and violence. Even at the very beginning of their journeys, leaving the war stage is possible through dangerous passages of the highly securitized borders, in the case of Syrian women two of those were the borders with Jordan and Lebanon. Leaving the war zone follows with numerous secondary movements and various border crossings. In many cases Syrian women on transit remain trapped in certain cities, zones or camps of displaced people. Those cities and camps are called connection points and serve as meeting points between smugglers and refugees/migrants. For example Beirut, Amman, Aqaba, Cairo, and Ajdabija are the important connection points on the way to Libya from Lebanon.

After 2012, both Lebanon and Jordan controlled and limited the passages of certain groups across their borders. Palestinian refugees, unaccompanied men, men without family ties in Jordan, and people without valid identity documents were prohibited from entering the Jordanian territories. After 2012-13 a majority of the Syrian refugees had to flee the neighboring borders via clandestine ways. All these borders were controlled by military forces thus all passages raised strong fears and feelings of insecurity among the Syrian women who had to rely on the smugglers or facilitators. The fears were caused also by the spreading stories of sexual violence and abuse that other Syrian girls and women had undergone during their border crossings around the region. ${ }^{18}$

Living on the border itself, especially in the case of Jordan, known with mandatory camp-based settlement, contains various gender-based challenges in the front of the Syrian women. ${ }^{19}$ After Jordan reduced its border gates from 45 to only 2 in 2014, around 75,000 refugees, mainly women

18 International Federation for Human Rights, Violence against women in Syria: Breaking the Silence, Briefing Paper, Jordan, 2012; Sharon Pickering, "Deadly Borders: Women and Children Seeking Asylum", The Conversation, 3 April 2013.

19 Because of these realities the $80 \%$ of the Syrian refugees inhabit the cities, villages, and informal tent settlements. Ayham Dalal, "Syrian Refugees in Jordan...", p.43. 
and children and elderly men remained stranded at nowhere on the SyrianJordan border zone, at the so called berms at Rukban and Hadalat. ${ }^{20}$ As in the case of Myanmar, Sudan and Thailand border camps, the border camps and in general the camps recall dangerous prison-like places of sexual abuse and harassment. In many cases the camps may become hyper militarized centers of armed groups that exercise sexual violence over the girls and women and forceful militarization of the boys. ${ }^{21}$ As in the example of Rukban camp car bombing in October and December 2016, the camps are often exposed to suicide bombings. So, the camps are especially dangerous for single women and mothers.

Both Lebanon and Jordan show a hostile approach towards the Syrians and call for "safe zones" established within the conflict prone Syria. This approach recalls insecurity among the Syrian refugees and strengthen the motives for leaving to other countries. Indeed, at the beginning of 2017, under vivid violation of the Arab Charter of Human Rights, Jordan initiated forceful deportations of Syrian men refugees suspected of posing threat to security in Jordan..$^{22}$ As it is well known, Syrian men use to cross the Syrian borders and check the situation in their village, see/visit/help some relatives or buy some local medicines. The apprehensions of the Syrian men during their border crossings as well as the deportations led to separation of many families, thus many women were left alone or became heads of families.

Being barred in a dessert area, the so called berm camps, constituted one of the main reasons behind the secondary movements among the Syrian women. Trapped in inhumane conditions Syrian families who had sufficient resources started to leave the berms and moved towards Syria or further away to Turkey, Italy or Spain. In general, while Syrian refugees that move to the EU-28 via Turkey follow the Aegean or the Balkan route, Syrian refugees from Lebanon, Jordan and Egypt use to cross the Mediterra-

20 Elena Fiddan-Qasmiyeh, "What 2017 could bring for milllions of displaced Syrians", PRI, 4 January 2017.

21 J. Hyndman, "Refugee Camps as Conflict Zones: The Politics of Gender", in W.Giles, J. Hydman ed., Sites of Violence: Gender and Conflict Zones, BerkeleyUniversity of California Press, 2004, p. 193-212.

22 HRW, I have no Idea Why they Sent us back: Jordanian Deporttions and Expulsions of Syrian Refugees, October 2017. 
nean borders of the EU. In 2013 Syrian refugees constituted 25 percent of the detected passages across the Libya-Italy sea border. ${ }^{23}$ Before the 'Arab spring' the passages through Mediterranean borders were regulated under smooth border security and remote control strategy negotiated among the EU and North African countries under initiatives for Partnership for Democracy and Prosperity Shared with the southern Mediterranean. Valetta Summit is the most cited initiation in this regard. Most of these initiatives did not stop the smuggling as well as trafficking through the Central Mediterranean, but led to a shift towards dangerous and expensive routes that resulted in more deaths at the border zones, deserts, and human traffickers' hubs. ${ }^{24}$

\section{Figure 2: Major Migration Routes and Hubs around the Euro-Meditterranean ${ }^{25}$}

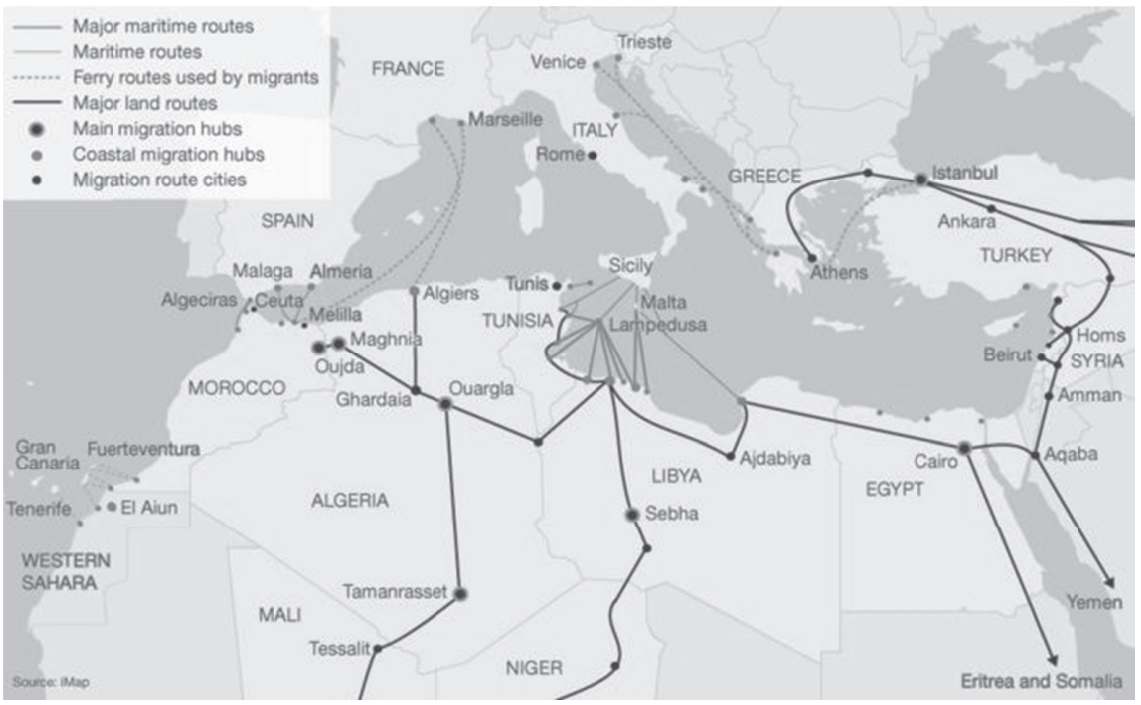

\section{Frontex Annual Risk Analysis, 2014}

24 Xavier Ferrer-Gallardo, Henk van Houtum, The Deadly EU Border Control, 2012; H. van Houtum, Boedeltje, F. "Europe's shame: Death at the borders of the EU", Antipode, No: 41 (2), 2009, p.226-230.

25 BBC News: Mapping Meditterranean Migration, 2013, www.imap-migration.org 
After the securitization of the blue borders along the Italian, Greek and Spanish shores the passages became more dangerous, more expensive with lots of crossroads with the human trafickers. Especially the launch of the Triton joint operation in 2014 at the Central Mediterranean has dropped the direct passages to Italy. Thus Syrian refugees who succeed to leave the berm camps had to walk/drive hundreds of kilometers through dangerous conflict zones and deserts and reach smugglers hubs in Tunisia, Ceuta, Cairo or Istanbul, Edirne or Izmir. After the launch of Triton and EU Naval Force Med Operation SOPHIA (EUNAVFORMed), especially after the beggining of 2015, Syrian refugees shifted their passages to the Eastern Mediterranean and Balkan routes. By 2016 Syrians constituted 53 percent of the migrants who crossed the Eastern Mediterranean, i.e. the Aegean route. ${ }^{26}$ (See Figure 2)

\section{Crossing The Mediterranean Through The Eyes Of Syrian Women}

The EU-initiated discriminative migration and border regimes across the Mediterranean caused thousands of refugees and migrants to choose clandestine movements to the EU. Prior to 2014 Syrian refugees looking for asylum in the EU, used to cross from Libya to Italy. After the EU launched the NATO assisted Poseidon Sea Rapid Intervention in the Easter Mediterranean (Aegean) in $2011^{27}$ the coastal region of Libya became the most intensive organized smugglers hub in North Africa. Both Libya and Egypt were considered as dangerous transit countries, yet, they constituted the main departure hubs for the refugees and migrants who wanted to reach the EU. This was the case for more than 45,000 Syrian refugees, as well. In 2012 these hubs became the main departure and passage points of the Syrian refugees heading for Italy. Indeed, more than 2,200 Syrian women used this route to cross to Italy in 2012 and 2013. ${ }^{28}$

The most dangerous part of this journey lasted throughout the long passage along the desert and countries with high rates of crime: Egypt and Libya.

\section{Frontex Annual Risk Analysis, 2016}

27 Frontex, Frontex and NATO to Cooperate in the Aegean Sea, 6 Mart 2016, http://frontex.europa.eu/news/

28 IOM, Human Traficking through the Central Mediterranean: Data, Stories and Information Collected by the IOM, Italy, October 2017. 
During our conversations with the Syrian women in Istanbul, they defined Libya as the most dangerous place a woman can find herself. They told stories about armed groups that control the desert and lots of stories they have heard about rapes and slave trade of young women and girls. ${ }^{29}$ The reports point to the high rate of pregnant women among the women who come to Italy from Libya. While Ugandan women for example use pregnancy as a strategy to avoid rapes and go faster through the state borders, this is not a case for the Syrian women. ${ }^{30}$ All of the Syrian women told stories about men as smugglers, as border guards, as facilitators, as soldiers, as militias who they had to avoid or pass safely. The concept of border evokes men, policemen, guns, nightmare, violence, uncertainty, long waiting, losing everything, lots of walking, fear of death, sexual abuse and rape among the Syrian women. ${ }^{31}$ Borders may also recall the border camps and detention centers, especially at the shores of the Mediterranean Sea.

Libya is also known for its overcrowded detention centers ill-famed for their devastating conditions, malnutrition, illnesses, physical violence, slavery markets, widespread sexual abuse and inhuman treatment of the refugees. Because of the high rates of bribes, gender-based violence and abusive approaches among the border guards and administrative staff, since the beginning of the war in Syria, Libya has never been a safe place especially for refugee women and children. Nevertheless, because of the war in Syria and insecurity and conflict in Iraq, until 2014 Libya constituted the closest passage hub for the Syrian refugees, who used to be approached as so called "wealthy passengers" ${ }^{32}$ within the local smuggling market. ${ }^{33}$ For example, the African women refugees and migrants often pay attention to the fact that Syrian refugees are being treated in a different manner by the smugglers and Libyan officials.

29 Similar cautions are included in the calls of www.awaremigrants.org

30 Interview with Ugandan women realized by Kasim Salihu, Istanbul, 15 September 2017

31 Notes from conversations with Syrian women in Şanlıurfa realized by Şule Gürle, May 2016

32 Conversations with the African migrants in Istanbul show that smugglers in Libya use to treat Syrian refugees better than African migrants and refugees, because of etnicracial disctimination and higher income reasons.

33 Kenneth Roth, How the EU can manage the migrant flow, HRW, 8 November 2017 
Indeed, the Libya-Italy route was actively used by the middle class Syrian refugee families during 2012-2014. At that time for Syrians from South Syria it was difficult to reach Turkey because of the distance, the ongoing conflict along the Syrian territories, the partly closure and strengthening of the border control in Turkey in 2015, and the activation of the search and rescue operations along the Eastern Mediterranean. After 2012 Syrian refugees moved towards Lebanon, Egypt or Libya. Those who had sufficient economic resources paid to the smugglers and crossed the Mediterranean to Italy. Those who lacked resources, remained in Egypt or Libya or moved to Saudi Arabia or Kuwait. In November 2014, border guards in Ceuta and Melilla recorded numerous asylum applications of Syrian families seeking asylum in Europe.

Prior to the initiation of the EU border and coast guard security operations in the Mediterranean and especially prior to Triton joint operations in 2014, the Euro-Mediterranean Sea passages increased 14 times from 2011 to $2014^{34}$. According to the IOM data Syrian women were the main passengers crossing Central Mediterranean in 2014. Around 6,203 Syrian women were detected on their journey from Libya to Italy. Their numbers fell to 1,237 in the following $2015 .{ }^{35}$ Indeed, accompanied by the NATO sea forces the Triton operations decreased the fraudulent passages in the Central Mediterranean after 2014. Before 2014 the clandestine passages had been managed through professional smuggling networks. Thus there were occasional deaths of migrants as result of catastrophe or climate shifts. After the launch of the EU-led Triton operations in Central Mediterranean the arrivals to the Eastern Mediterranean shores reached 204,542 Syrians, Afghans and Eritreans in 2014, and 1 million in 2015. ${ }^{36}$

After EU launched the Frontex-coordinated Triton and Sophia search and rescue operations the refugees and migrants had to face with high technology paramilitary coast guard boats and surveillance systems. The passages became riskier and expensive. Women who had sufficient economic

\footnotetext{
$34 \quad$ Frontex Annual Risk Analysis, 2015

35 IOM, Human Traficking Through the Central Mediterranean Route: Data, Stories, and InformationCollected by the IOM, 2017, p.10.

36 Tara Brian, Frank Laczko, "Introduction: Migrant Deaths around the world in 2015", Fatal Journeys, Identification and tracing of dead and missing migrants, Vol. 2, IOM, 2016.
} 
resources continued their journeys or found jobs and settled in Egypt. Some women remained in Libya or Egypt while their husbands continued to the EU-28. There are many cases of single, widow or unaccompanied successful and emancipated Syrian women refugees living in the EuroMediterranean region. ${ }^{37}$ Nevertheless, majority of Syrian women were left out of resources and could not afford another trip to the Western or Eastern Mediterranean hubs and remained in Libya or Egypt. The attempt to cross to the other shore left them more disempowered and vulnerable than before. Some of those who succeed to collect sufficient resources moved to Morocco and the Spanish border, yet, Spain controls one of the EuroMediterranean passages known for its highest rate of deportations at the borders.

The restrictive EU asylum and migration policies prevent many refugee women from access to asylum. Syrian women fail to access asylum as well. Those who could not cross the Mediterranean and have got trapped in Libya or Egypt have had no other option than working in the informal sector for extremely low wages, finding accommodation in poor and unsafe suburbs, accepting forced marriage, or doing sex work. Some of them have been deceived by the traffickers through promises of well-paid jobs in Italy and headed to cross the borders under the guidance of the human traffickers. Those women are usually indebted (around 25,000 Euros) while some of them enslaved upon their arrival in Italy. Such debts never end and those women end up trapped in the Italian black market or move forward to EU countries with high rate of black market and slavery. All of these options leave tremendous burden on the shoulders of the Syrian women. Refugee women health reports talk about high rates of anxiety, poor self-esteem, depression, mistrust, poor cooperation, fear etc. Psychological or behavioural disorders are common among the refugee women on the move. ${ }^{38}$

37 Maysa Ayoub, "Gender, social class and exile: The case of Syrian Women in Cairo", A Gendered Approach to the Syrian Refugee Crisis, Jane Freedman, Zeynep Kivilcim, Nurcan Ozgur Baklacioglu eds, London: Rootledge, 2016, p.86-96.

38 Sharon Pickering, Rebecca Powell, "Death at the Sea: Migration and the Gendered Dimentions of Border Insecurity", A Gendered Approach to the Syrian Refugee Crisis, Jane Freedman, Zeynep Kivilcim, Nurcan Özgür Baklacıoğlueds., London: Routledge, 2017, p.105-112; UNHCR, UNFPA, WRC, Initial Assesment Report: Protection Risks for Women and Girls in the European Refugee and Migrant Crisis- Greece and Former Yugoslav Republic of Macedonia,2016, www.unhcr.org 
After 2015, as result of the EU borderization policies the Libya-Italy route became the most dangerous route in the Mediterranean. (See Figure 3) In 2015, the death rate at the Mediterranean Sea was around one in 269 successful passages and the number of refugees and migrants who succeed to cross the Mediterranean Sea was more than 1 million. In 2016, the accomplished passages remained at 327,800 and the death rate increased to one dead migrant/refugee per every 73 successful crossings. ${ }^{39}$ More than 10,400 men, women and children have died or gone missing trying to reach Europe via the Euro-Mediterranean route during 2016. In the same year every day 2 children lost their lives or disappeared at the Mediterranean Sea borders. ${ }^{40}$. Especially during the winter, the survival rates fall tremendously. According to the IOM data, the relative death rate on this smuggling route claim one in every 92 refugees and migrants. Beside this in 2016 more than 20,600 child refugees and migrants, 18,400 of these unaccompanied crossed the Euro-Mediterranean border via this route. By the increase in the number of unaccompanied children on the move, this route became a grave for children fleeing war, persecution and extreme poverty in the Middle East and Africa. ${ }^{41}$

39 Philipe Fargues, Sara Bonfanti, When the best option is a leaky boat: why migrants risk their lives crossing the Mediterranean and what Europe is doing about it, Migration Policy Centre, European University Institute, Florence, October 2014.

40 Georgina Stubbs, "Refugee crisis: 600 children have died crossing Mediterranean in 2016", The Independent, 2 October 2016.

41 Mirren Gidda, “As Rotes to Europe Close, Refugees are starting to consider one of the oldest and deadliest Crossings", Newsweek, 4 December 2016 
Figure 3: Death Tolls at the Euro-Mediterranean Borders ${ }^{42}$

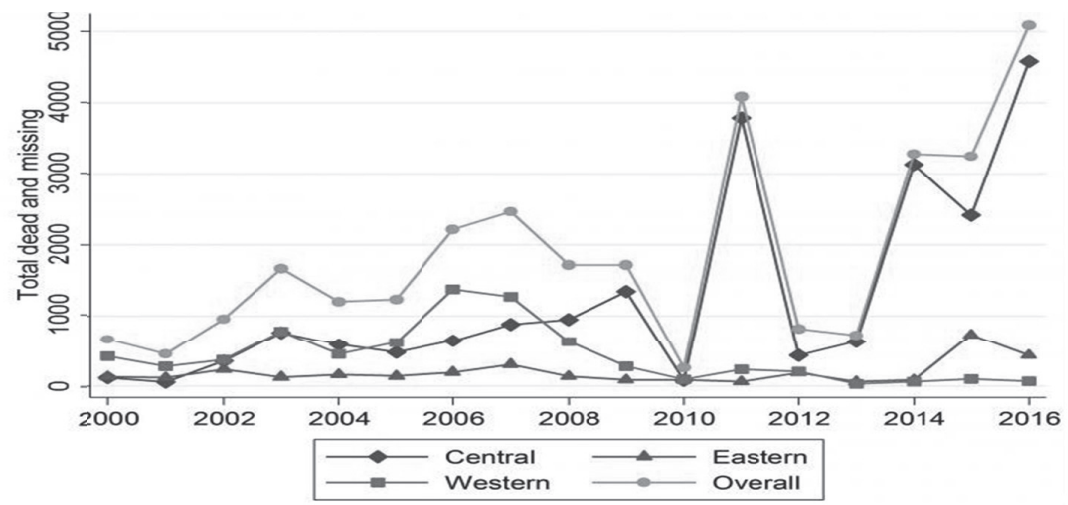

After 2015, the Libya-Italy route has been used primarily by the African migrants and refugees with lower payment capabilities. This shift in the profile of the smuggled refugees led to change in the smugglers chains and smuggling services as well. The boats became old, left in poor quality, without any safety equipment. Passages became more dangerous especially for the women with limited resources who had to travel at the bottom of the rubber boats.

\section{Figure 4: Exemplary Data on the EU operations at the Mediterranean $^{43}$}

\begin{tabular}{|l|l|l|}
\hline Year of Initiation & Operations and Funds & Budget (Euro) \\
\hline 2011-continue & Operation Poseidon & $\begin{array}{l}18,000,000 \\
\text { Euros per year }\end{array}$ \\
\hline $2014-$ continue & Operation Triton & $34,800,000$ Euros per year \\
\hline $2007-2013$ & EU External Borders Fund & $1,800,000,000$ \\
\hline 2015 & $\begin{array}{l}\text { EU Border Expenses during } \\
\text { the Great refugee passage }\end{array}$ & $3,800,000,000$ \\
\hline $2014-2020$ & EU Border and Migration Fund & $15,680,000,000$ \\
\hline
\end{tabular}

42 Tamara Last and Thomas Spijkerboer, Tracking Deaths in the Mediterranean, Working Paper, SSRN, 2014

43 Nurcan Özgür Baklacıŏlu, Uluslararası Sinırların Gölgesinde Mülteci Kadınlar, İstanbul, Derin Yayınları, 2017, p. 154 
Beside the irresponsibility and abuses of the smugglers, many studies argue that especially the initiation of the Frontex joint search and rescue operations and the Triton operation at the Central Mediterranean was followed by an increase in the deaths at the Euro-Mediterranean borders.(See Figure 4) Indeed, while in 2014, 3,538 people lost their lives in the Mediterranean ${ }^{44}$, after the intensification of the search and rescue (SAR) operations in the Mediterranean in 2015 UNHCR and IOM Missing Migrants Project announced that 3,771 people lost their lives in the Mediterranean. This number increased to 5,096 deaths in $2016 .{ }^{45}$ (See Figure 5)

According to the European Parliament, the activation of these SAR operations decreased the death toll in the Euro-Mediterranean zone. However, the overall trend in the data in Figure 5 shows that there was an increase in the deaths after the beginning of the above mentioned operations. One may say that the operations gave visibility to the already occurring deaths, and claim that thousands of refugees were saved instead. Certainly it is true that hundreds of people were rescued at the middle of the sea, yet, it is also true that there is an ongoing vicious circle. In this vicious circle of violence the increase in the border deaths leads to strengthening the control at the borders and increase in border patrolling and search operations and fight against the smuggling networks. This border securitization leads to uncertainty, last minute changes in the routes, and refugees and migrants have to pay higher prices for more dangerous and hard voyages to the EU.

Figure 5: Demography of Mediterranean Sea Arrivals ${ }^{46}$

\begin{tabular}{|l|l|l|l|}
\hline Previous years & $\mathbf{2 0 1 4}$ & $\mathbf{2 0 1 5}$ & $\mathbf{2 0 1 6}$ \\
\hline Sea arrivals & 216,054 & $1,015,078$ & 362,753 \\
\hline Dead and missing & 3,538 & 3,771 & 5,096 \\
\hline \multicolumn{2}{|l}{ Gender\&Age: Men \%60; Women \%20; Children \%20 } \\
\hline
\end{tabular}

44 "Yüzlerce Göçmen Taşıyan Gemi Alabora Oldu", BBC News, 6 Ağustos 2015.

45 IOM, Missing Migrants Project, 2016.

46 UNHCR, Demography of Mediterranean sea arrivals from January 2017, Source: http://data2.unhcr.org/en/situations/mediterranean 
All that on the other hand resulted in more deaths because of the dangerous strategies, hunts and run away tactics of the smugglers. Many refugee boats sink during intensive hunts between the coast guards and smugglers or refugees. During such dangerous journeys to the EU or even to the neighbouring countries many refugee families get separated. Mothers lose their kids, the kids lose their parents. Migrants and refugees get injured, some disappear. The fear and all this trauma lasts for years and leaves deep wounds in the lives of the Syrian women. According to gender-based analysis of the deaths at the sea, the women refugees and migrants are more vulnerable to death in the sea than at the land borders. ${ }^{47}$

The Central Mediterranean Sea is particularly dangerous for fast track maneuvers, especially when talking about overcrowded and old wooden or rubber boats. Indeed, after the beginning of the joint operations the Syrian refugee movement across the Central Mediterranean shifted to the Aegean, Balkan and Black Sea routes. According to the IOM data, in 2015 just 7,448 Syrians used the Central Mediterranean route while 478,898 Syrians transited from Turkey to Greece. There were no Syrian refugees detected at the Central Mediterranean routes until early 2017 when as a result of the implementation of the EU-Turkey readmission agreement in $2016^{48}$ the Syrian refugees started to join African refugees at Lampedusa, Malta, and Sicily in the Mediterranean again. ${ }^{49}$ According to the available data, women constitute about 20 percent of the migrants and refugees who passed the Mediterranean Sea borders during the last decade. It is stated that the children constitute the other 20 percent of the migrants and refugees moving on this route. Other studies claim that women constitute half of the refugees and migrants that undertake those dangerous journeys. ${ }^{50}$

There is no comprehensive data about the number of Syrian women that succeed to reach the desired EU destination country. The Eurostat sources

47 Sharon Pickering, B. Cochrane, "Irregular Border Crossing Deaths and Gender: Where, How, and Why Women Die Crossing Borders", Theoretical Criminology, No: 17/1, 2013, p.27-48

48 European Union-Turkey Agreement Between the European Union and the Republic of Turkey on the Readmis-Sion of Persons Residing Without Authorisation, Pub.L.No. L134/3, 2014, http://eur-lex.eu-ropa.eu/legalcontent/

49 "More Than 200 Migrants Feared Drowned in Mediterranean", BBC News, 23 Mart 2017.

$50 \quad$ Pickering, Death at sea..., p.107-8 
do not provide gender-based data about the Syrian asylum applicants in the EU. In addition, the married Syrian women are usually registered under the file of the whole family and get residence permit through the application of their husband or father. The single Syrian women are rather prone to be trafficked and thus left out of their documents and ID cards. Thus, it is not very easy to find data about the Syrian women in most of the EU-28. The Eurostat analysis point to women refugees (including children) as constituting 50 percent of the whole Syrian refugees that applied for asylum in the EU-28.

For difference from African women, the Syrian women appear stick to family ties and rules, thus they seek safety through the family networks. However, for the sake of more safety the Syrian women keep silence and obey to the hierarchy and violence in the private space. The poverty may not end even when they settle in the EU-28. The already accumulated trauma agglomerates under the cultural discomfort and fear of deportation or another resettlement. This tension may result in more violence in the domestic space. Approached as survival and safety strategy, forced marriages strike as one of the main problems that young Syrian women face in the private space. A Syrian mother looked at her daughter and said: "I wish she do not undergo her menstruation soon, because we will have to marry her in order to protect her". ${ }^{51}$ The fear of sexual harassment and rape seems to design their lives across the borders.

Nevertheless, for difference from the African women, the Syrian women are not under a threat of deportation or refoulement at the borders of the EU because Syria is not in the EU Safe Country of Origin list. Thus, the Syrian women who succeed to reach the desired final destination in the EU, place application for asylum and receive a legal residence permit to stay in the country under temporary protection.

\section{Conclusion: Strong borders, more safety for women?}

The introduction of the Schengen zone and code followed multiplication of complex migration management policies based on tough and exclusionary

51 Nurcan Özgür Baklacioğlu, Notes from a personal interview with a Syrian women in Fatih, Istanbul, 2014. 
visa policies and tight border regimes. This led to discriminative migration and border regimes that caused thousands of refugees and migrants to choose clandestine movements to the EU. The rise in the demand resulted in the multiplication of transnational smuggling and trafficking market.

The correlation between the border security measures and the number of the deaths at the blue borders, followed by the change in the main clandestine routes during the last 20 years shows that the strengthening of the border security and migration control leads to the growth of the smuggling market and human trafficking. The rise in the human trafficking on the other hand raised insecurity especially among the unaccompanied and single refugee women and children. The wars, interventions and conflicts in the Middle East, South Asia and Africa not only led to physical violence and death of thousands of people at war, but they aggregated a huge regional market based on gender-based violence that extends across borders.

To distinguish from men, the refugee women, in our case the Syrian women experience gender-based violence and sexual abuse all along their run from the war zone up to the destination countries in Europe. The whole journey takes place under a bitter struggle to survive various masculine borders at the camps, border crossings, smugglers' hubs, desert crossings, transit, and destination countries. These phenomena point to the formation and growth of a kind of Euro-Mediterranean black market based on the exploitation of women and children refugees and migrants. ${ }^{52}$ The available data shows that the so called black market produces more than 60 percent of GDP of the African countries. ${ }^{53}$ At the global level it extends beyond 1 trillion US Dollars. ${ }^{54}$

Instead of targeting the growing black market, the expensive and militarized border security measures and SAR operations undertaken by the EU and its European Border and Coast Guard Agency end up targeting the

52 Jacqui True, "The Political Economy of Violence Against Woman: A Feminist International Relations Perspective", Australian Feminist Law Journal, Number 32/1, 2010.

53 Ramazan Kılıç, Özer Özçelik, "Küresel Bir Sorun: Kayıtdısı Ekonomi”, Dumlupınar Üniversitesi Sosyal Bilimler Dergisi, Say1 16, Aralık 2006, p. 337-358.

54 Willem Van Schendel, Itty Abraham, "Introduction: the Making of Illicitness", Illicit Flows and Criminal Things: States, Borders and the Other Side of Globalisation, Willem Van Schendel, Itty Abraham (Ed.), Indiana University Press, Indianapolis, 2005, p. 1-40. 
smugglers, thus the migrants and refugees. The Frontex and EBCG agency operations cause constant shift in the smuggling channels, increase in the transportation fees paid to the smugglers, and force thousands of women into debt bondage extending across the Euro-Mediterranean. Thanks to the SAR operations the smugglers and traffickers are becoming more and more professionalized and transnationally organized.

There is an emergent need of studies and policies investigating and challenging the broad and complex dimensions of the broadening Euro-Mediterranean black market grounded on illicit trade and rapidly growing human trafficking extending from Africa and Middle East up to the North European countries. ${ }^{55}$ The states spend growing expenditures and mobilize extensive military and border guard support to fight smuggling and intercept the clandestine passages. For example, the NATO-assisted Triton operation was supported by $24 \mathrm{EU}$ member states which provided 293 to 400 specialized border security guards, 15 coast guard boats and a monthly budged of 2.9 million Euros.(See Figure 4) Moreover, all above mentioned EU-financed SAR operations are supported or connected to a complex network of various data registration, security, surveillance, information etc. services and programs involving thousands of specialists and officers such as SIS, EUROSUR, VIS, EURODAC, Europol, CEPOL, EMCDDA, EASO and EU-LISA as well as numerous local national border security agencies and technical services of Euro-Mediterranean countries. ${ }^{56}$ All these institutions form a huge transnational border security industry that absorbs millions of euros, drastic part of the national GDP's, but do not bring any sustainable solution, instead lead to more violence and insecurity for both people and states. ${ }^{57}$ Instead of keeping on with those enormously growing expenditures, the Euro-Mediterranean states and the EU have to challenge the regional informal and black markets that obviously grow based on social and sexual exploitation and abuse of their vital clients: the irregular migrant and refugee women.

55 The Global Initiative against Transnational Organised Crime, Integrated Responses to Human Smuggling from the Horn of Africa to Europe, May 2017.

56 Frontex, Archive of Operations - JO EPN Poseidon Sea (As of 28.12.2015 - Poseidon Rapid Intervention), 8 Ağustos 2016, http://frontex.europa.eu/operations/; Frontex, Frontex Launches Joint Operation Triton, 31 October 2014, http://frontex.eu-ropa.eu/ news/frontex-launches-joint-operation-triton

57 Nurcan Özgür Baklacıoğlu, Uluslararası Sinırların...,p.151-161 


\section{Bibliography}

"More Than 200 Migrants Feared Drowned in Mediterranean", BBC News, 23 March 2017.

"Yüzlerce Göçmen Taşıyan Gemi Alabora Oldu", $B B C$ News, 6 Ağustos 2015.

Ayoub, Maysa, "Gender, social class and exile: The case of Syrian Women in Cairo", in A Gendered Approach to the Syrian Refugee Crisis, Jane Freedman, Zeynep Kivilcim, Nurcan Ozgur Baklacioglu eds, London: Rootledge, 2016, p.86-96.

Brian, Tara, Frank Laczko, "Introduction: Migrant Deaths around the world in 2015", Fatal Journeys, Identification and tracing of dead and missing migrants, Vol. 2, IOM, 2016.

Dalal, Ayham, "Syrian Refugees in Jordan: Potentials, Challenges and the Right to the City", International Community and Refugees: Responsibilities, Possibilities and Human Rights Violations, Turkey: Amnesty International, 2016, p.41-47.

European Commission, Study on the Gender Dimension of the Trafficking in Human Beings, Publications Office of the European Union, Lüksemburg, 2016, p.4.

European Union-Turkey Agreement Between the European Union and the Republic of Turkey on the Readmission of Persons Residing Without Authorisation, Pub.L.No.L134/3, 2014

Fargues, Philipe, Sara Bonfanti, When the best option is a leaky boat: why migrants risk their lives crossing the Mediterranean and what Europe is doing about it, Migration Policy Centre, European University Institute, Florence, October 2014.

Ferrer-Gallardo, Xavier. Henk van Houtum, The Deadly EU Border Control, 2012

Fiddan-Qasmiyeh, Elena, "What 2017 could bring for milllions of displaced Syrians", PRI, 4 January 2017.

Fiddian-Qasmiyeh, Elena, "Palestinian and Syrian Refugees in Lebanon: Sharing Space, Electricity and the Sky", Refugee History, 22 December 2016, www.refugeehistory.org 
Freedman, Jane, "Engendering Security at the Borders of Europe: Women Migrants and the Mediterranean 'Crisis"'. Journal of Refugee Studies. Number 29/4. 1 December 2016.

Frontex Annual Risk Analysis, 2014

Frontex Annual Risk Analysis, 2016

Frontex Annual Risk Analysis, 2015

Frontex, Archive of Operations - JO EPN Poseidon Sea (As of 28.12.2015 - Poseidon Rapid Intervention), 8 August 2016.

Frontex, Frontex and NATO to Cooperate in the Aegean Sea, 6 Mart 2016, http://fron-tex.europa.eu/news/

Frontex, Frontex Launches Joint Operation Triton, 31 October 2014.

Gidda, Mirren, "As rotes to Europe close, refugees are starting to consider one of the oldest and deadliest crossings", Newsweek, 4 December 2016

HRW, I have no idea why they sent us back: Jordanian deporttions and expulsions of Syrian refugees, October 2017.

Hyndman, J. "Refugee Camps as Conflict Zones: The Politics of Gender", W.Giles, J. Hydman ed., Sites of Violence: Gender and Conflict Zones, BerkeleyUniversity of California Press, 2004, p.193-212.

International Federation for Human Rights, Violence against women in Syria: Breaking the Silence, Briefing Paper, Jordan, 2012

IOM, Human Traficking through the Central Mediterranean: Data, Stories and Information Collected by the IOM, Italy, October 2017.

IOM, Missing Migrants Project, 2016.

Kesgin, H, A.Öztürk, "The bitter truth behind Syrian War: Desperate Widows", Anadolu Agency News, 10 February 2014

Kılıç, Ramazan, Özer Özçelik, "Küresel Bir Sorun: Kayıtdısı Ekonomi”, Dumlupınar Üniversitesi Sosyal Bilimler Dergisi, Say1 16, Aralık 2006, p. 337-358.

Last, Tamara, Thomas Spijkerboer, Tracking Deaths in the Mediterranean, Working Paper, SSRN, 2014. 
Newman, David, "Boundaries, Borders and Barriers: Changing Geographic Perspectives on Territorial Lines", (Ed.) M. Albert at all, Identities, Borders and Orders, University of Minnesota Press, Minneapolis, 2001

Orhan, Oytun, The Situation of Syrian Refugees in the Neighbouring Countries: Fingings, Conclussions and Recommendations, ORSAM Report No: 189, Ankara, April 2014

Özgür Baklacıoğlu, Nurcan. Uluslararası Sinırların Gölgesinde Mülteci Kadınlar, İstanbul, Der Yayınları, 2017.

Paasi, Anssi, "The Changing Discourses on Political Boundaries: Mapping the Backgrounds, Contexts and Contents", Henk Van Houtum, Olivier Kramsch, Zierhofer Wolfgang (Ed.), B/Ordering Space, Ashgate, London, 2005, p.17-31

Pickering, Sharon, "Deadly Borders: Women and Children Seeking Asylum", The Conversation, 3 April 2013.

Pickering, Sharon, B. Cochrane, "Irregular Border Crossing Deaths and Gender: Where, How, and Why Women Die Crossing Borders", Theoretical Criminology, No: 17/1, 2013, p.27-48

Pickering, Sharon, Rebecca Powell, "Death at the Sea: Migration and the Gendered Dimentions of Border Insecurity", A Gendered Approach to the Syrian Refugee Crisis, Jane Freedman, Zeynep Kivilcim, Nurcan Özgür Baklacioğlu eds., London: Routledge, 2017, p. 105-112

Pickering, Sharon, Women, Borders, and Violence: Current Issues in Asylum, Forced Migration. Springer. New York. 2011.

Ramsay, Kathryn, "The Situation of Refugee Women in Lebanon", International Community and Refugees: Responsibilities, Opportunities, Human Rights Violations, Amnesty International (ed.),Istanbul, 2016, p.33-41

Roth, Kenneth, How the EU can manage the migrant flow, HRW, 8 November 2017

Stubbs, Georgina, "Refugee crisis: 600 children have died crossing Mediterranean in 2016", The Independent, 2 October 2016.

The Global Initiative against Transnational Organised Crime, Integrated Responses to Human Smuggling from the Horn of Africa to Europe, May 2017. 
Tinas, Murat, "Syrian Refugees in Lebanon: Economic, Political, and Sectarian Challenges in the absence of Governmental Strategy", ORSAM Review of Regional Affairs, No.62, May 2017

True, Jacqui, "The Political Economy of Violence Against Woman: A Feminist International Relations Perspective". Australian Feminist Law Journal. Number 32/1, 2010.

UNHCR, Demography of Mediterranean Sea arrivals from January 2017, Source: http://data2.unhcr.org/en/situations/mediterranean

UNHCR, Refugees/Migrants Emergency Response-Mediterranean, 2016.

UNHCR, UNFPA, WRC, Initial Assesment Report: Protection Risks for Women and Girls in the European Refugee and Migrant Crisis- Greece and Former Yugoslav Republic of Macedonia, 2016, Available at: www. unher.org

Van Houtum, H., Boedeltje, F. "Europe's shame: Death at the borders of the EU", Antipode, No: 41 (2), 2009, p.226-230.

Van Houtum, Henk. "The Geopolitics of Borders and Boundaries", Geopolitics, No/4/10, November 2005, p. 672-679.

Van Schendel, Willem. Itty Abraham, "Introduction: the Making of Illicitness", Illicit Flows and Criminal Things: States, Borders and the Other Side of Globalisation, Willem Van Schendel, Itty Abraham (Ed.), Indiana University Press, Indianapolis, 2005, p.1-40. 